\title{
An albumin-like protein in the serum of non-parasitic brook lamprey (Lampetra appendix) is restricted to preadult phases of the life cycle in contrast to the parasitic species Petromyzon marinus
}

\author{
Mehmet H. Danis, Michael F. Filosa *, John H. Youson \\ Department of Zoology, Division of Life Sciences, University of Toronto at Scarborough, 1265 Military Trail, Toronto, \\ Ont., Canada M1C $1 A 4$
}

Received 24 March 2000; received in revised form 5 July 2000; accepted 6 July 2000

\begin{abstract}
Previous work showed that the parasitic sea lamprey, Petromyzon marinus, has two different albumin-like serum proteins during the course of its life cycle. One of these, AS, is the predominant protein in the serum of larval and metamorphosing intervals but is absent in the upstream migration phase of the life cycle; the other, SDS-1, is found at its highest level in the upstream migration phase and is the predominant serum protein in this phase. The present investigation examines the nonparasitic brook lamprey Lampetra appendix for the presence of albumins. Using electrophoresis and antisera monospecific for serum proteins, it was found that L. appendix has a serum protein that is antigenically similar to the AS protein of $P$. marinus. This protein (LAS) makes up about $70 \%$ of the total serum protein of the Lampetra larva, is present in metamorphic stages 1,2,3,4 and 5 but is virtually absent from the remaining metamorphic stages and the adult. Furthermore, the adult of L. appendix has no serum protein that is antigenically similar to SDS-1 of the adult $P$. marinus; our study shows that, unlike $P$. marinus, there is no single protein that represents a major portion of the total serum protein content in the L. appendix adult. (C) 2000 Elsevier Science Inc. All rights reserved.
\end{abstract}

Keywords: Adaptation; $\alpha$-Fetoprotein; Immunoelectrophoresis; Lamprey; Lampetra appendix; Metamorphosis; Petromyzon marinus; Serum albumin; Serum proteins

\section{Introduction}

Previous work in this laboratory has been concerned with examining serum proteins of the landlocked lamprey Petromyzon marinus for qualitative and quantitative changes that might be related to the phases of the animal's life cycle

\footnotetext{
* Corresponding author. Tel.: + 1-416-2877404; fax: + 1416-2877642.

E-mail address: filosa@scar.utoronto.ca (M.F. Filosa).
}

(Filosa et al., 1982, 1986; Filosa et al,. 1992; Filosa et al., 1998). This extant member of the primitive group of jawless fishes (Agnatha) begins its life as an eyeless larva inhabiting rivers and streams. After 3-7 years of feeding and growing, the larva initiates a process of metamorphosis, involving morphological and biochemical changes, that extends over a period of 4 to 5 months during which the animal does not feed (Youson and Potter, 1979; Youson, 1980). As a result of metamorphosis the larva is transformed 
into a parasitic juvenile that feeds off the blood and tissues of teleost fish to which it attaches itself. After about 12-20 months of this parasitic way of life, the animal has increased its weight about 70 -fold and sexual maturation begins. The animals will migrate up streams and rivers where they will spawn and shortly thereafter, die (Youson, 1980).

Our initial studies focused on a protein that was reported to first appear in the upstream migrant (Rall et al., 1961). We later found that this protein, designated SDS-1 by us, is, in fact, present in small amounts at earlier intervals but is the most abundant serum protein in the upstream migrant, constituting about $40 \%$ of the total serum protein (Filosa et al., 1982). It is a glycoprotein with a molecular mass of about $175 \mathrm{kDa}$ and is synthesized in the liver of the upstream migrant (Ito et al., 1988). By isolating cDNA clones of the gene for the SDS-1 protein, Gray and Doolittle (1992) derived its amino acid sequence and found that this lamprey protein had an amino acid composition and sequence that placed it in the albumin multigene family which includes vertebrate serum albumin, $\alpha$-fetoprotein and vitamin $\mathrm{D}$ binding protein. They concluded that the mature protein is the lamprey plasma albumin and consists of 1,394 amino acids with a molecular mass of $157 \mathrm{kDa}$. Based on the number of potential glycosylation sites, they estimated that the molecule could have a molecular mass up to $175 \mathrm{kDa}$. Unlike serum albumins of higher vertebrates that consist of three 190-amino acid domains, the lamprey albumin has seven such domains, making it what they called an oversize albumin.

When the serum proteins of the larval phase were examined, it was found that the most abundant serum protein was one that, based on electrophoretic and immunological studies, was not present in the upstream migrant (Filosa et al., 1986). This protein was designated AS. It is also a glycoprotein, has a mass of about $160 \mathrm{kDa}$, makes up about $70 \%$ of the total serum protein of the larva and early metamorphosing animals, and is synthesized by the liver (Ito et al., 1988). In juveniles, about $40 \%$ of the total serum protein is AS but in the upstream migrant adults the level of AS drops to less than $0.5 \%$. When a partial cDNA clone of the AS gene was isolated, the derived amino acid sequence specified by the clone was shown to be $40 \%$ identical to that of the
SDS-1 albumin found at the upstream migrant phase (Filosa et al., 1998). Thus, in P. marinus there are two different genes coding for two proteins similar to each other and similar to serum albumin of higher vertebrates. AS predominates in the larva, metamorphic and juvenile phases while the SDS-1 albumin-like protein does so in the upstream migrant. We proposed that $\mathrm{AS}$, because of its absence in the sexually mature upstream migrants, was analogous to the $\alpha$-fetoprotein of higher vertebrates which is normally restricted to embryonic, fetal and neonatal phases (Filosa et al., 1998).

The existence of two different serum albumins in the lamprey $P$. marinus raises questions about the function of these molecules at the biochemical level as well as the adaptive significance of the shift from AS to SDS-1 for the life of the lamprey. While serum albumin is known to function in higher vertebrates to maintain colloid osmotic pressure of the blood and to transport various ligands, there is no direct evidence concerning the physiological function of the two albumin-type molecules in P. marinus. It is possible that the two albumins have differing binding capacities to reflect the difference in ligands to be bound at various phases of the life cycle. As for adaptive significance, the shift from AS to SDS-1 as the major albumin-like protein in P. marinus could be related to the change to a parasitic existence after metamorphosis. In addition, since the landlocked $P$. marinus is genetically related to the anadromous form, the shift from AS to SDS-1 might be a genetically programmed event that, in the anadromous form, has adaptive value for the migration from freshwater to seawater after metamorphosis.

In order to relate the shift in albumin-like molecules to some role in the life cycle, it became of interest to determine whether these two albumin-like proteins were employed by another species of lamprey which has a life style quite different from that of P. marinus. Lampetra appendix, the American brook lamprey, is a nonparasitic, exclusively freshwater species. The larva undergoes metamorphosis but unlike $P$. marinus there is no parasitic phase after metamorphosis. All the growth of the animal occurs from the feeding which takes place only during the larval phase and perhaps the first two stages of metamorphosis (Holmes et al., 1999). As a result, the mature adults weigh even less than premetamor- 
phic larvae and approximately 40 times less than $P$. marinus adults. Within 4 or 5 months after completing metamorphosis, the nonfeeding adults become sexually mature, spawn and die, having spent their entire life in the same freshwater stream. Perhaps, the differences in life style between $L$. appendix and $P$. marinus might be reflected in differences in the quantitative and/or stage-specific expression of the albumins; such differences may provide clues to understanding the function of these two proteins as well as their adaptive significance.

\section{Materials and methods}

\subsection{Animals}

Lampetra appendix larvae were obtained from Duffins Creek in Pickering, Ontario by electroshocking. They were kept in tanks containing $10 \mathrm{~cm}$ of stream sediment and dechlorinated tap water at $9^{\circ} \mathrm{C}$ with flow through circulation. They were fed once a week with a suspension of baker's yeast ( $1 \mathrm{~g}$ of yeast per animal). Larvae collected in June were followed through their metamorphosis which commenced in July and terminated approximately 5 months later in December. During this time the animals went through seven stages of metamorphosis (Holmes et al., 1999). Subsequent development resulted in sexually mature adults. Metamorphic and sexually maturing animals were both kept under similar conditions as the larvae except they were not fed during these two nontrophic intervals. The sex of adult animals was determined by identification of gonads after dissection.

\subsection{Blood collection and serum separation}

Blood was taken from larvae throughout the year. For metamorphosing animals, blood was collected at the various stages between July and December. Adults were sampled in December and during the spring and summer months. Animals to be bled were anaesthetized using $0.05 \%$ tricaine methanesulfonate (Syndel, British Columbia) before their weight and length were recorded. The tail was severed below the cloaca and blood was collected from the caudal vein in microhematocrit capillary tubes. The blood was allowed to clot at room temperature for $1 \mathrm{~h}$, then stored for $12 \mathrm{~h}$ at $4^{\circ} \mathrm{C}$. The serum was separated by centrifugation at room temperature and stored at $-20^{\circ} \mathrm{C}$.

\subsection{LAS purification}

LAS, the most abundant protein in L. appendix serum, was isolated electrophoretically. Whole serum $(15 \mu \mathrm{l})$ was electrophoresed $(220 \mathrm{~V}, 2 \mathrm{~h})$ in $1 \%(\mathrm{w} / \mathrm{v})$ agarose (Low $M \mathrm{r}$ electrophoresis grade; Biorad, CA) using 0.015 M Laurel buffer, pH 8.6 in the gel and also as the electrode buffer (Laurell, 1965). The leading anodal band was cut out after detection with anilinonaphthalene sulfonate (Hartman and Udenfriend, 1969). The piece of agarose containing the leading band was minced with a razor blade and the pieces placed on a small wad of glass wool in a $0.5 \mathrm{ml}$ micocentrifuge tube with a pin hole at the bottom. The tube was kept at $-70^{\circ} \mathrm{C}$ to freeze the gel. The gel was allowed to thaw and the tube was placed into a $1.5 \mathrm{ml}$ microcentrifuge tube; the assembly was then centrifuged at $5000 \times g$ to collect the eluted protein in the lower tube.

The purity of the eluted protein was analyzed by crossed immunoelectrophoresis (CIE) and polyacrylamide gel electrophoresis (PAGE) as described below.

\subsection{Polyacrylamide gel electrophoresis (PAGE)}

Polyacrylamide gels were prepared with a $7.5 \%$ separation gel and a $0.5 \mathrm{~cm}, 4 \%$ stacking gel; serum was mixed with an equal volume of sample buffer to give a final concentration of $1 \%$ SDS and $10 \% \beta$-mercaptoethanol (Takacs, 1979). The samples were heated in boiling water for $5 \mathrm{~min}$. Gels were run at $75 \mathrm{~V}$ for $7 \mathrm{~h}$ at room temperature then stained with Coomassie Blue R250 $(0.25 \%$ in $50 \%$ methanol, $10 \%$ acetic acid) for $1 \mathrm{~h}$ and destained with methanol-acetic acid-water (8:1:11). Glycoproteins were detected on the gels by a periodic acid-Schiff method (Zacharius et al., 1969).

\subsection{Antibody production}

Polyclonal antisera against whole serum or isolated serum proteins were produced by hyperimmunizing New Zealand White rabbits as reported previously (Filosa et al., 1982; Ito et al., 1988). Briefly, a rabbit was injected subcutaneously in the shoulder region with a $1: 1$ mixture of serum or 
protein solution and complete Freund's adjuvant followed two weeks later by a second injection at the same site with the antigen in incomplete Freund's adjuvant. Rabbits were bled from the marginal ear vein. After the blood clotted, serum was separated by centrifugation and stored at $-20^{\circ} \mathrm{C}$. Preimmune serum was obtained from each rabbit prior to any injection.

\subsection{Crossed immunoelectrophoresis (CIE)}

Crossed immunoelectrophoresis was carried out essentially as described previously (Filosa et al., 1982, 1986). A glass plate $(70 \times 70 \mathrm{~mm})$ was used as a support for a $1 \%(\mathrm{w} / \mathrm{v})$ agarose gel (Low $\mathrm{Mr}$ electrophoresis grade; Biorad, CA) in $0.015 \mathrm{M}$ Laurel's buffer at pH 8.6 (Laurell, 1965). This same buffer was used for the electrode chamber solution.

For electrophoresis, $4 \mu \mathrm{l}$ of serum or protein was placed into $3 \mathrm{~mm}$ diameter wells cut out of the agarose. The first dimension was run at a constant voltage of $220 \mathrm{~V}$ for $1 \mathrm{~h}$ and $45 \mathrm{~min}$. The plates were kept from heating up by cold water flowing through the platform supporting the glass plates. The second dimension utilized one of the antisera prepared against whole serum or isolated protein.

\subsection{Immunodiffusion}

Immunodiffusion plates were prepared and wells $4 \mathrm{~mm}$ in diameter were cut out of the agarose (Hudson and Hay, 1976). Serum, antiserum and purified protein samples were placed in marked wells and kept at $4^{\circ} \mathrm{C}$ and examined periodically for up to $72 \mathrm{~h}$. When immunodiffusion was completed, the gel was washed extensively in water, air dried on glass, then stained with Coomassie blue as mentined above for PAGE.

\subsection{Protein assay}

Protein was assayed by a Coomassie Blue method (Bradford, 1976) using bovine serum albumin as a standard. Each sample was assayed in triplicate and the average of these values was used.

\subsection{Rocket immunoelectrophoresis}

Rocket immunoelectrophoresis was used to quantitate levels of LAS using a procedure previ- ously employed (Weeke, 1973; Filosa et al., 1992). To produce the standard curve, $3 \mathrm{~mm}$ holes were cut in $1 \%(\mathrm{w} / \mathrm{v})$ agarose plates containing $300 \mu \mathrm{l}$ of antiserum against the LAS protein. Known amounts of LAS protein $(4 \mu \mathrm{l})$ were placed in wells in duplicate; $4 \mu \mathrm{l}$ of serial dilutions of $L$. appendix serum from a single animal were placed, in duplicate, in wells on the same plate. The electrophoresis was conducted at constant voltage of $40 \mathrm{~V}$ for $14 \mathrm{~h}$. The plates were then pressed, stained and destained as in the CIE procedure. The heights of rockets were measured from the center of the well. The heights of rockets produced by known amounts of LAS protein were plotted against the amount of protein to obtain a standard curve (Filosa et al., 1992). To ensure that all serum rockets fell within the range of the standard curve, the range of AS standards was varied depending on the period of the life cycle from which the samples were obtained. The height of the rocket produced by a given sample was read against the standard curve to determine the amount of LAS in the sample. Each time samples were assayed, a standard curve was run on the same gel.

\subsection{Statistics}

Student's $t$-test was used to evaluate differences between measurements for specific phases.

\section{Results}

When larva serum of $L$. appendix is electrophoresed on $1 \%$ agarose, a major band of protein, designated LAS, is found migrating in the anodal direction (Fig. 1). LAS protein was eluted from the agarose and was electrophoresed by PAGE for comparison with whole serum from various periods of the L. appendix life cycle. LAS (Fig. 2, lane 2) has a molecular mass of about 150 $\mathrm{kDa}$ and appears to be the predominant protein staining in the larva and in metamorphosing stages one through five (Fig. 2 lanes 3-6). Sera from metamorphic stage seven and adults lack a major band corresponding to the LAS protein (Fig. 2 lanes 7,8); the faint bands seen in these lanes might suggest the same protein is present in much lower amount. Staining PAGE gels for glycoprotein indicated that LAS is a glycoprotein. 


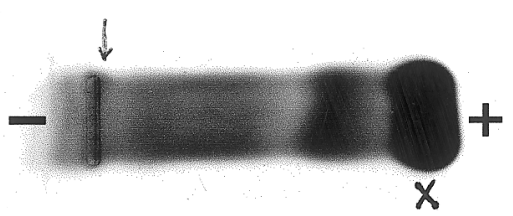

Fig. 1. Electrophoresis of L. appendix serum on agarose; gel stained with Coomassie Blue. $15 \mu \mathrm{l}$ of larva serum was applied to a rectangular well at the cathodal end of the gel. The leading, anodal band $(\mathrm{X})$ is LAS; $(+)$ and $(-)$ show polarity. The arrow indicates the well in which the sample was initially applied.

To confirm that the $150 \mathrm{kDa}$ band seen in the PAGE gels is the same protein in the larva and metamorphic stages, crossed-immunoelectrophoresis (CIE) was employed. Sera from larvae, stage five metamorphic animals and adults were electrophoresed against a polyclonal antiserum made against whole serum from $L$. appendix larvae. Representative results are shown in Fig. 3. The area under a loop is directly proportional to the amount of a given antigen in the serum. A major loop common to all three serum

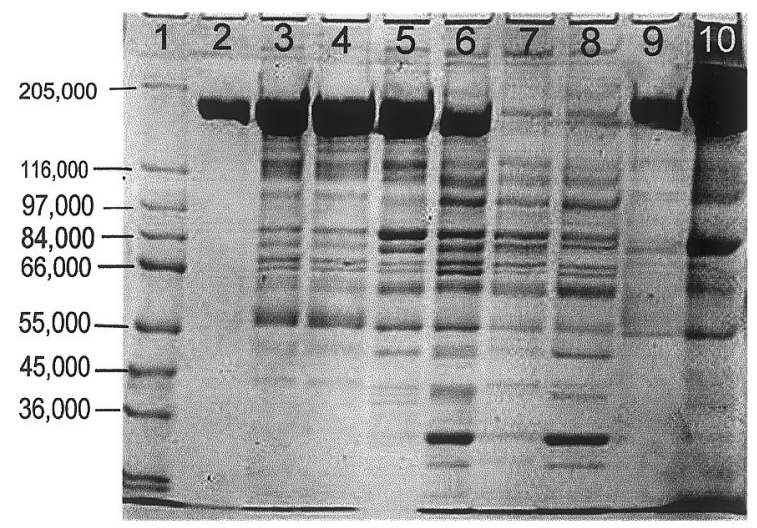

Fig. 2. PAGE of purified LAS protein and sera from various phases of L. appendix and P. marinus. Wells three to ten were loaded with serum from a single animal of the appropriate stage, amounting to $30 \mu \mathrm{g}$ of protein; the gel was stained with Coomassie Blue. Lane 1, molecular mass markers; lane 2, purified LAS protein isolated from pooled larva serum, approx. $150 \mathrm{kDa}$; lane $3, L$. appendix larva serum; lane $4, L$. appendix metamorphic stage one serum; lane 5, L. appendix metamorphic stage three serum; lane 6, L. appendix metamorphic stage five serum; lane 7, L. appendix metamorphic stage six serum; lane $8, L$. appendix adult serum; lane 9, P. marinus larva serum showing predominant AS protein, approx. 160 $\mathrm{kDa}$; lane 10, P. marinus adult serum showing predominant SDS-1 protein, approx. $175 \mathrm{kDa}$. The major serum proteins in the $P$. marinus larva and the adult are antigenically different, as discussed in the text.

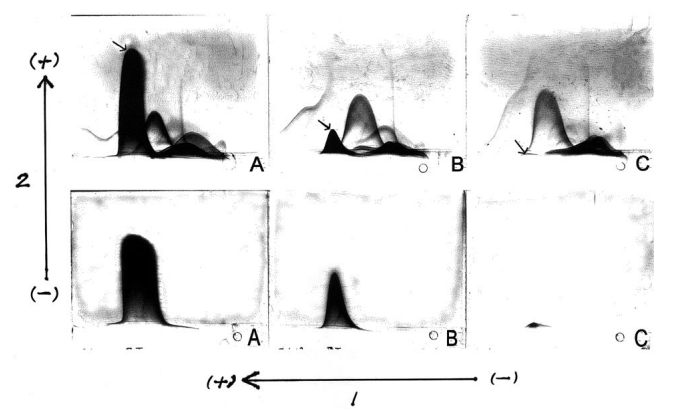

Fig. 3. Changes in the LAS serum protein of different phases of $L$. appendix life cycle detected by CIE on agarose gels; immunoprecipitates stained with Coomassie Blue. Top row: all gels in this row were run using an antiserum made against whole larva serum of L. appendix. Bottom row: all gels in this row were run using an antiserum monospecific for the LAS protein. The circle to the left of each letter represents the well in which the sample was applied. The large arrows indicate the direction and polarity of the first (1) and second (2) electrophoretic runs. In both rows, the same letter represents serum from the same individual animal. A, larva serum; B, metamorphic stage five; $\mathrm{C}$, adult. In the top row, the loop of the LAS immunoprecipitate is indicated by a small arrow; the other loops represent other serum proteins common to larva, metamorphic animal and adult.

samples is identified by its location along the horizontal axis of each pattern (Fig. 3 top row, arrows). This loop has the greatest area in the larva; the area of the corresponding loop for the metamorphic animal is reduced (Fig. 3 top row, B) and for the adult serum, a loop is barely visible (Fig. 3, top row, C). These data suggest that the quantity of a certain protein decreases significantly during the life cycle. The other loops in these patterns represent other larval antigens that are common to all three intervals of the life cycle (Filosa et al., 1982, 1986).

That the loops indicated (Fig. 3, top row) correspond to the LAS protein was definitively determined by running the same serum samples against an antiserum made against the purified LAS protein. The single loops shown (Fig. 3, bottom row, $\mathrm{A}, \mathrm{B}, \mathrm{C})$ correspond to the loops indicated by arrows in the top row (Fig. 3). Together, these results show that the LAS protein is present at different levels in the different phases of the life cycle and is almost totally absent from the adult. Results similar to these were observed for sera from six groups of animals covering the same phases.

In order to quantitate the changes in LAS over the entire life cycle, the method of rocket elec- 
trophoresis (Weeke, 1973; Filosa et al., 1992) was performed with serum samples from individual animals and a polyclonal rabbit antiserum monospecific for LAS protein (Fig. 4). Only rockets that fell within the range of the standards were used for quantitation. Total serum protein for each serum sample was also measured. The data presented in Fig. 4 also indicate the number of animals assayed for each interval. Larva serum contains about $26 \mathrm{mg} \mathrm{ml}^{-1}$ of LAS which represents about $70 \%$ of the total serum protein. By metamorphic stage four, the amount of LAS drops significantly to $13 \mathrm{mg} \mathrm{ml}^{-1}(p<0.001)$ and comprises, on average, about $66 \%$ of the total serum protein. By metamorphic stage five, the LAS protein is reduced to about $10 \mathrm{mg} \mathrm{ml}^{-1}$ but, because there is also a decrease in total serum protein, it still makes up $60 \%$ of the total serum protein. A drastic decrease in LAS content is seen between stage five and six $(p<0.001)$, in which the level is $0.18 \mathrm{mg} \mathrm{ml}^{-1}$, making up only about $2 \%$ of the total serum protein. The stage seven animals and the adults, both male and female, show essentially no LAS in the serum. During the course of these developmental changes the amount of total serum protein decreased significantly from a high of $36 \mathrm{mg} \mathrm{ml}^{-1}$ in the larva to about $8 \mathrm{mg} \mathrm{ml}^{-1}$ in the female adult $(p<0.001)$.

Our previous studies on $P$. marinus (Filosa et al., 1982, 1986; Ito et al., 1988) had shown that in that species AS was the major protein of the larva (Fig. 2, lane 9) and metamorphic stages, but was absent in the upstream migrant adult. Instead, the predominant serum protein of the upstream migrant adult is another serum protein, SDS-1 (Fig. 2, lane 10). It had been shown that these two proteins are antigenically distinct and that SDS-1 had an inverse quantitative relation to AS: it was present at a low level in the earlier stages when AS was dominant, but was the predominant protein in the upstream migrant adult when AS was absent.

To determine if the AS protein of $P$. marinus had any similarity to the LAS protein of $L$. appendix, CIE was done using an antiserum monospecific for the LAS protein. The specificity of this antiserum is seen in Fig. 5A as shown by the single CIE loop resulting with whole serum from an L. appendix larva. When serum from a larva of $P$. marinus is run against the same antiserum, a single loop appears (Fig. 5B), indicating that this serum contains a protein with antigenic similarity to the LAS of L. appendix. From its location, the loop can be identified as an immunoprecipitate of the AS protein (Filosa et al., 1982; Ito et al., 1988).

In another CIE run, antiserum monospecific for AS of P. marinus (Filosa et al., 1986) crossreacted with the purified LAS of L. appendix (data not shown). In addition, tandem CIE (Weeke, 1973) using AS and LAS proteins run against antiserum monospecific for LAS produced loops which showed continuity, indicating that they have antigenic similarity; a similar result was seen when

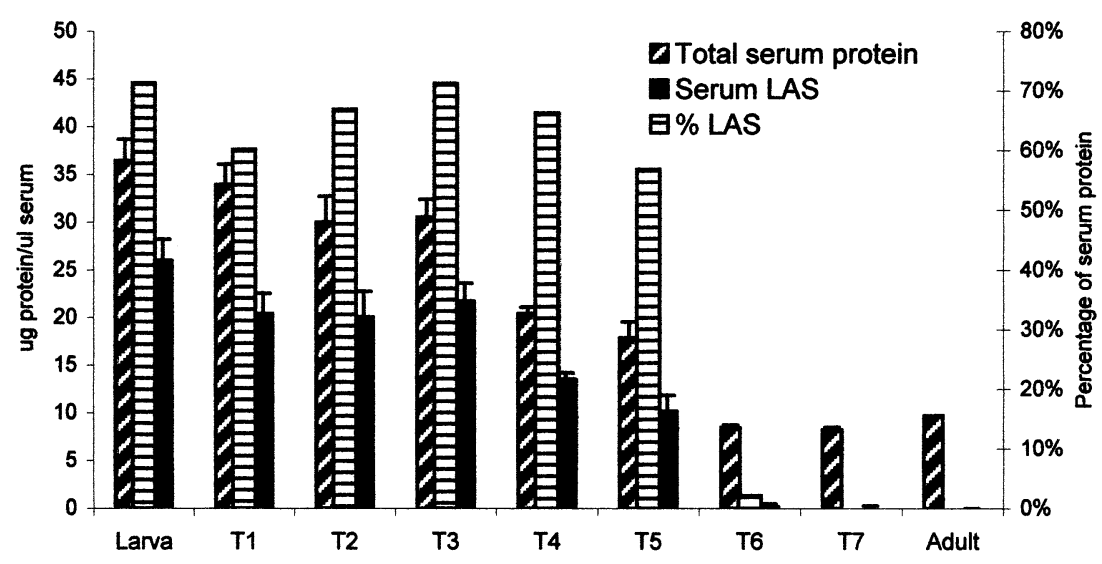

Fig. 4. Quantitative analysis of LAS protein and total protein at various phases of the life cycle. The amount of LAS per $\mu$ l of serum (Serum LAS) was determined by rocket immunoelectrophoresis, using purified LAS for the standard curve. Full details given in Section 2. Total protein was determined colorimetrically (Bradford, 1976). T1-T7, stages one to seven in the metamorphic process. The number of individual animals used for these measurements is as follows: Larva, five; T1, three; T2, five; T3, four; T4, four; T5, four; T6, six; T7, four; Adult (males and females), 13. $\% \mathrm{LAS}=$ serum LAS/total serum protein $\times 100$. 


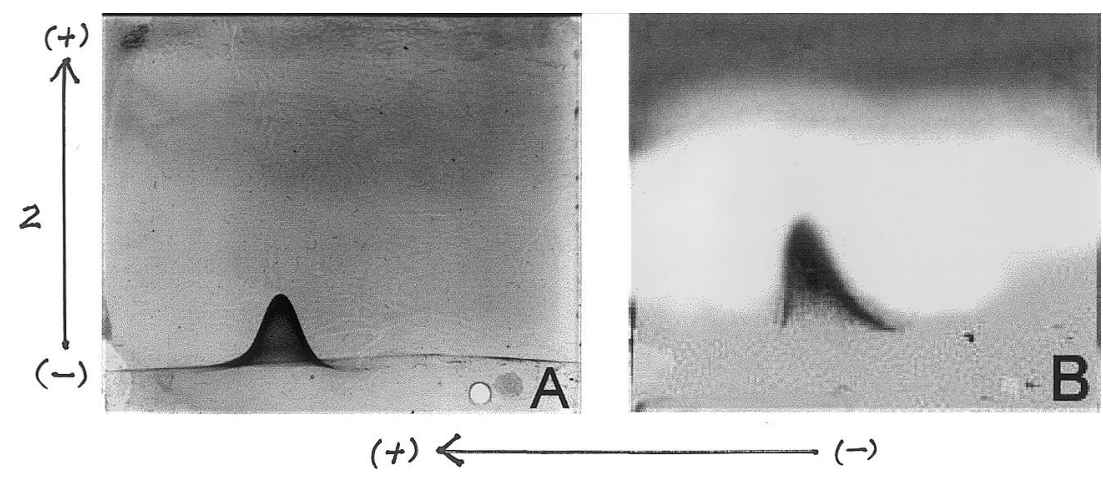

Fig. 5. CIE analysis to show antigenic similarity between LAS of $L$. appendix and AS of $P$. marinus. Panel A, whole larva serum of $L$. appendix run against an antiserum monospecific for LAS. Panel B, whole larva serum of $P$. marinus run against the same antiserum used in A. The circle represents the well where the sample was applied. The arrows indicate the direction and polarity of the first (1) and second (2) electrophoretic runs. Immunoprecipitates stained with Coomassie Blue.

antiserum against AS was used in the analysis (data not shown). These results indicating similarity of antigenic determinants between the LAS and AS proteins were borne out by immunodiffusion analysis (Fig. 6). The continuous arc of immunoprecipitate formed by LAS and AS proteins diffused against anti-LAS antiserum indicates that the two proteins have identical antigenic determinants. The immunoprecipitate formed by the two proteins diffused against anti-AS antiserum shows a spur indicating that that AS and LAS have determinants in common but AS has additional determinant(s) not found in LAS.

Unlike $P$. marinus adults that replace the AS albumin protein of the earlier phases, electrophoresis of serum from L. appendix adults showed no predominant protein (Fig. 2, lane 8) to make up for the loss of the LAS protein. In order to determine if the L. appendix adult serum nevertheless contained a protein antigenically similar to the SDS-1 of $P$. marinus, the adult serum was used in CIE against an antiserum that was monospecific for the SDS-1 protein. No loop of immunoprecipitate was found (data not shown), suggesting that the $L$. appendix adult does not express a second albumin-like protein that resembles antigenically the SDS- 1 of $P$. marinus.

\section{Discussion}

The results of this study indicate that $L$. ap pendix has a serum protein, LAS, that resembles the AS protein of P. marinus in two respects: first, antigenic similarity and secondly, distribution during the life cycle of the animal. With regard to antigenic similarity, our study showed that a polyclonal antiserum made against isolated LAS protein crossreacted with the isolated AS protein of $P$. marinus, indicating that the two proteins have one or more epitopes in common. In addition, a polyclonal antiserum made against isolated AS protein of $P$. marinus crossreacted with the isolated LAS protein and also suggests antigenic similarity between the two proteins.

LAS, like AS, was present in highest concentration in the larval phase and was absent or barely detectable in the mature adult. However, there was a difference between the two species during the period of metamorphosis: LAS of L. appendix declined from its high level in the larva and was

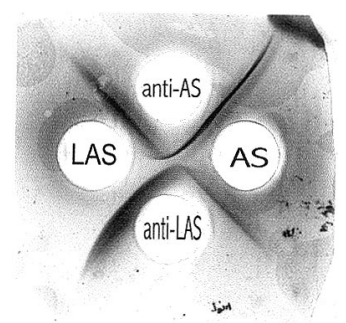

Fig. 6. Antigenic similarity of LAS and AS as determined by immunodiffusion in agarose. Wells were filled $(10 \mu \mathrm{l})$ with antiserum monospecific for LAS (anti-LAS) or AS (anti-LAS). A solution of purified LAS protein (LAS) or AS protein (AS) was placed in other wells. After $48 \mathrm{~h}$ of diffusion at $4^{\circ} \mathrm{C}$, immunoprecipitates were visible. The agarose was washed, air-dried, then stained with Coomassie Blue. A continous immunoprecipitate is observed when AS and LAS are diffused against anti-LAS. A continuous immunoprecipitate and a spur are observed when the same two proteins are diffused against anti-AS. 
essentially absent in metamorphic stages six and seven while in $P$. marinus, there was also a decline in AS protein during metamorphosis but there was still a high level of AS in the final stage of metamorphosis (stage seven) and in the early juvenile phase where it constituted about $40 \%$ of the total serum protein.

The present work also shows that the two species are different with respect to the SDS-1 albumin-like protein of adult P. marinus (Filosa et al., 1982, 1986). This protein constituted about $40 \%$ of the total serum protein of the mature adult $P$. marinus and was readily detected in PAGE gels as an approximately $175 \mathrm{kDa}$ band (Filosa et al., 1982; Gray and Doolittle, 1992). PAGE of serum from adults of $L$. appendix showed no predominant protein at any molecular mass, suggesting that this species lacks a protein analogous to the adult serum albumin of $P$. marinus. As further support for this, antiserum made against the isolated SDS-1 did not crossreact with any protein in the L. appendix adult serum.

Previously, we found that the AS protein of $P$. marinus belongs to the albumin multigene family and, because of its predominance in the pre-adult phases of the life cycle, we proposed that it may serve the function of an $\alpha$-fetoprotein (Filosa et al., 1998). Based on its antigenic similarity to AS, the LAS protein described here for L. appendix may also have a similar function. Supporting the view that LAS has an exclusively preadult role, is the fact that, unlike in $P$. marinus, LAS is not replaced after metamorphosis by another albumin-like protein. In these respects L. appendix is similar to a number of species of sharks in which a serum $\beta$-globulin, considered to be an $\alpha$-fetoprotein, is present in the fetal stage only (Gitlin et al., 1973). Further evidence for an $\alpha$-fetoproteinlike serum protein in fish comes from studies on rainbow trout (Ohkawa et al., 1987; Sarcione and Black, 1994). In the case of the sharks and the rainbow trout, the designation of the serum protein as $\alpha$-fetoprotein-like is based on functional studies; the determination of the primary structure of the protein has not been done and so, unlike the data on the lamprey AS protein, it is not known whether these proteins are members of the albumin multigene family which includes $\alpha$-fetoprotein. Regardless, the existence of these $\alpha$-fetoprotein-like molecules in lamprey, sharks and a teleost has great significance for understanding the phylogeny of $\alpha$-fetoprotein in vertebrates. We have discussed this matter previously (Filosa et al., 1998) and a very comprehensive review of the phylogeny has been published by Mizejewski (1995).

Two major functions of albumin in higher vertebrates are the maintenance of colloid osmotic pressure and the transport of a variety of ligands including fatty acids and thyroid hormone (Peters, 1996). If these same functions are carried out by lamprey albumins, then the lack of an albuminlike protein in the L. appendix adult raises questions about how the animal compensates for the loss of these functions, if it does compensate. As for the osmotic function, our results indicate that the large amount of LAS that is lost when the animal undergoes transformation is not replaced by another prominent plasma protein. In fact, the data indicate that the total plasma protein content in the last two stages of metamorphosis and the adult of $L$. appendix is approximately $70 \%$ less than that of the earlier intervals. Either these animals compensate for the consequent reduction in colloid osmotic pressure, for example by a drop in blood pressure, or the reduction has no significant consequences for the life of the animals despite the fact that they are in the same aquatic environment as in earlier phases.

In the matter of transport capacity, the lack of albumin may not be serious because the later transformer stages and the adult are nontrophic and, as far as fatty acids are concerned, would probably not be handling the same amounts as in the trophic stages of the life cycle. Indeed, it has yet to be determined whether the lamprey albumins are carriers for fatty acids or any other ligand. It is known that serum of the Pacific lamprey, L. tridentata, contains a $19 \mathrm{kDa}$ protein that binds palmitate, but it is not a member of the albumin superfamily (Peters and Davidson, 1991).

The almost complete absence of albumin, analbuminemia, is known to occur in vertebrates (Peters, 1996). In humans this is a recessive trait that leads, in almost all cases, to no immediate serious consequences but, according to recent epidemiological evidence, reduced albumin levels are associated with increased mortality risk (Bourdon et al., 1999) Nagase et al. (1979) bred a strain of rats in which plasma albumin was about 7000 times lower than in normal rats but these analbuminemic animals exhibited no serious abnormalities. As for fish, Metcalf and her coworkers have recently reported that in two species of New 
Zealand eels (Anguilla dieffenbachii and A. australis schmidtii) (Metcalf et al., 1999a) and another teleost, the Antarctic toothfish, Dissostichus mawsoni (Metcalf et al., 1999b) there is no albumin present. In these teleosts, the transport of fatty acids is carried out by a high density lipoprotein (HDL) which constitutes the major plasma protein and as such also contributes to the colloid osmotic pressure. Similar findings have been reported for the common carp, Cyprinus carpio (De Smet et al., 1998). In the case of elasmobranchs, analysis using classical dye-binding procedures indicated the absence of albumin but the matter needs to be investigated more thoroughly (Ballantyne, 1997).

For L. appendix, there is a possible adaptive significance not in the absence per se of the albumin but rather in its failure to be synthesized. Eliminating the synthesis of this molecule during the time of sexual maturation would spare the use of materials and energy that could be used for gamete production. The SDS-1 albumin-like molecule consists of about 1400 amino acid residues (Gray and Doolittle, 1992) and given the fact that, during translation alone, four energyrich bonds are required for the formation of each peptide bond, the investment in materials and energy in synthesizing an L. appendix equivalent of this polypeptide, in amounts similar to LAS in the larva, would be substantial. Such an investment of resources would have to be made at a time in the life cycle when the animal is not feeding and in fact exhibits a decrease in mass (Holmes et al., 1999) and is producing gametes. In contrast, after metamorphosis, a P. marinus adult grows by parasitic feeding to about 100 times the mass of the larva and could potentially have the energy and materials to make substantial amounts of its own albumin, SDS-1, as well as become sexually mature.

The absence of an albumin-type molecule in the L. appendix adult could have resulted from the loss of the gene for the SDS-1 polypeptide during the history of the lampreys. It is also possible that the gene is present but the absence of the protein results from a failure to express the SDS-1 gene due to some change in its cis-regulatory region or in another gene that is involved in regulating the SDS-1 gene. We are currently trying to determine whether L. appendix has a gene, similar to the $P$. marinus gene, that codes for an adult albumin-like protein similar to SDS-1.

\section{Acknowledgements}

The authors extend sincere thanks to Dr John A. Holmes (University of Guelph, Ontario, Canada) for providing most of the animals used in this study and for his helpful comments on part of the discussion. This study was supported by a grant from the Natural Science and Engineering Council of Canada (JHY) and a contract from the Great Lakes Fisheries Commission (JHY, MFF).

\section{References}

Ballantyne, J.S., 1997. Jaws: the inside story. The metabolism of elasmobranch fishes. Comp. Biochem. Physiol. 118B, 703-742.

Bourdon, E., Loreau, N., Blache, D., 1999. Glucose and free radicals impair the antioxidant properties of serum albumin. FASEB J. 13, 233-244.

Bradford, M.M., 1976. A rapid and sensitive method for the quantitation of microgram quantities of protein utilizing the principle of protein-dye binding. Anal. Biochem. 72, 248-254.

De Smet, H., Blust, R., Moens, L., 1998. Absence of albumin in the plasma of the common carp Cyprinus carpio: binding of fatty acid to high density lipoprotein. Fish. Physiol. Biochem. 19, 71-81.

Filosa, M..F., Sargent, P.A., Fisher, M.M., Youson, J.H., 1982. An electrophoretic and immunoelectrophoretic characterization of the serum proteins of the adult lamprey, Petromyzon marinus L. Comp. Biochem. Physiol. 72B, 521-530.

Filosa, M.F., Sargent, P.A., Youson, J.H., 1986. An electrophoretic and immunoelectrophoretic study of serum proteins during the life cycle of the lamprey Petromyzon marinus L. Comp. Biochem. Physiol. 83B, 143-149.

Filosa, M.F., Ito, M.A., Youson, J.H., 1992. Quantitative changes in a serum protein, AS, during the life cycle of the lamprey, Petromyzon marinus L. Fish. Physiol. Biochem. 9, 417-426.

Filosa, M., Adam, I., Robson, P., Heinig, J., Smith, K., Keeley, F., Youson, J., 1998. Partial clone of the gene for AS protein of the lamprey Petromyzon marinus, a member of the albumin supergene family whose expression is restricted to the larval and metamorphic phases of the life cycle. J. Exp. Zool. 282, 301-309.

Gitlin, D., Perricelli, A., Gitlin, J.D., 1973. The presence of serum $\alpha$-fetoprotein in sharks and its synthesis by fetal gastrointestinal tract and liver. Comp. Biochem. Physiol. 46B, 207-215.

Gray, J.E., Doolittle, R.F., 1992. Characterization, primary structure and evolution of lamprey plasma albumin. Protein Sci. 1, 289-302. 
Hartman, B.K., Udenfriend, S., 1969. A method for immediate visualization of proteins in acrylamide gel and its use for preperation of antibodies to enzymes. Anal. Biochem. 30, 391-394.

Holmes, J., Chu, H., Khanam, S., Manzon, R., Youson, J., 1999. Spontaneous and induced metamorphosis in the American brook lamprey, Lampetra appendix. Can. J. Zool. 77, 959-971.

Hudson, L., Hay, F.C., 1976. Practical Immunology. Blackwell Scientific, Oxford, UK.

Ito, M.A., Filosa, M.F., Youson, J.H., 1988. In vitro study of serum protein synthesis in the livers of larvae and adults of the lamprey, Petromyzon marinus L. J. Exp. Zool. 245, 256-263.

Laurell, C., 1965. Antigen-antibody crossed immunoelectrophoresis. Anal. Biochem. 10, 358.

Metcalf, V., Brennan, S., Chambers, G., George, P., 1999a. High density lipoprotein (HDL), and not albumin, is the major palmitate binding protein in New Zealand long-finned (Anguilla dieffenbachaii) and short-finned eel (Anguilla australis schmidtii) plasma. Biochim. Biophys. Acta 1429, 467-475.

Metcalf, V., Brennan, S., George, P., 1999b. The Antarctic toothfish (Dissostichus mawsoni) lacks plasma albumin and utilises high density lipoprotein as its major palmitate binding protein. Comp. Biochem. Physiol. 124B, 147-155.

Mizejewski, G.J., 1995. The phylogeny of alpha-fetoprotein in vertebrates: survey of biochemical and physiological data. Crit. Rev. Eukaryot. Gene Expr. 5, 281-316.

Nagase, S., Shimamune, K., Shumiya, S., 1979. Albumin-deficient rat mutant. Science 205, 590-591.

Ohkawa, K., Tsukada, Y., Nunomura, W., Ando, M., Kimura, I., Hara, A., Hibi, N., Hirai, H., 1987. Main serum protein of rainbow trout (Salmo gaird- nerii ): its biological properties and significance significance. Comp. Biochem. Physiol. 88B, 497-501.

Peters, T. Jr., 1996. All About Albumin: Biochemistry, Genetics and Medical applications. Academic, San Diego, CA.

Peters, T. Jr., Davidson, L.K., 1991. Isolation and properties of a fatty acid-binding protein from the pacific lamprey (Lampetra tridentata). Comp. Biochem. Physiol. 99B, 619-623.

Rall, D., Schwab, P., Zubrod, C., 1961. Alterations of the plasma proteins at metamorphosis of the lamprey Petromyzon marinus dorsatus. Science 133, 279-280.

Sarcione, E.J., Black, J.J., 1994. Elevated serum levels of the alpha fetoprotein (AFP)-like immunoreactivity in rainbow trout, Onchorhynchus mykiss (Walbaum), with aflatoxin B1 induced hepatocellular carcinoma. J. Fish Dis. 17, 219-226.

Takacs, B., 1979. Electrophoresis of proteins in polyacrylamide slab gels. In: Lefkovits, I., Pernis, D. (Eds.), Immunological Methods. Academic, New York, pp. 81-105.

Weeke, B., 1973. The serum proteins identified by means of Laurell crossed electrophoresis. Scand. J. Clin. Lab. Invest. 25, 269-275.

Youson, J.H., 1980. Morphology and physiology of lamprey metamorphosis. Can. J. Fish. Aquat. Sci. 37, 1687-1710.

Youson, J.H., Potter, I.C., 1979. A description of the stages in metamorphosis of the anadromous sea lamprey, Petromyzon marinus L. Can. J. Zool. 57, 1808-1817.

Zacharius, R.M., Morrison, J., Zell, T., 1969. Glycoprotein staining following electrophoresis and polyacrylamide slab gels. Anal. Biochem. 30, 148-152. 